Vol. I No. 3 - December 2020

\title{
The Socio-hydrological Impacts of Oil Palm Plantations on Integrated Watershed Management:
}

\author{
Insights from Malaysia and Ways Forward \\ Taishi Yazawa ${ }^{1}$ and Yoshihisa Shimizu ${ }^{2}$ \\ Department of Civil and Environmental Engineering, Ritsumeikan University, Kusatsu, Japan ${ }^{1}$ \\ Research Center for Environmental Quality Management, Kyoto University, Otsu, Japan ${ }^{2}$ \\ yazawa-t@fc.ritsumei.ac.jp
}

\begin{abstract}
This paper aims to investigate the feasibility of flood management based on the concept of Integrated Watershed Management (IWM) via a literature review and field surveys. The investigation focused on the primary industry of oil palm plantations in Malaysia. Although the country is promoting the palm oil industry, the impact of oil palm plantations on the local environment has been relatively disregarded because of the benefits and opportunities, such as subsidies, jobs, and amenities, which the local companies/people can obtain. Effective flood management in oil palm plantations entails the local peoples' understanding and participation in the management activities, such as removing fallen leaves and weeding an area. The flood management strategies suggested in this research provide new insights into local flood management, which usually focuses on the hydrologic aspects, by promoting the integration of the actual-local environment and local people's actions for their environment within the framework of IWM.
\end{abstract}

Keywords: Integrated Watershed Management, Oil Palm Plantation, Flood Management, Malaysia

ARTICLE INFO

Received: Aug 20, 2020

Received in revised form: Aug 23, 2020

Accepted: Aug 24, 2020
JISDeP - The Journal of Indonesia Sustainable Development Planning Published by Centre for Planners'

Development, Education, and Training (Pusbindiklatren),

Ministry of National Development Planning/ National Development

Planning Agency (Bappenas), Republic of Indonesia
Address: Jalan Proklamasi 70 ,

Central Jakarta, Indonesia 10320

Phone: +62 $2131928280 / 3192828$

Fax: +62 2131928281

E-mail: pusbindiklatren@bappenas.go.id

Supported by Indonesian Development Planners Association (PPPI) 


\section{Introduction}

Flooding is one of the most common and serious problems in Southeast Asian countries, particularly during the monsoon season. Malaysia is one of the most sensitive and vulnerable areas to climate change in Southeast Asia because of its monsoonal climatic characteristics (T., Kim, Sato, \& Shimizu, 2019b). Malaysian watersheds have historically suffered from severely damaging floods that are common in monsoon climates. Rapid land-use changes, such as urbanization and deforestation, affect watershed hydrology. Poor river management and ineffective flood control regulations exacerbate the flooding in Malaysia (Chan, 1997). Although the Department of Irrigation and Drainage (DID), which manages water resources in Malaysia across the board, is the acknowledged authority in flood control, its legislative power is weak when it comes to making decisions regarding the development of rivers or the land adjacent to the rivers because the local governments or authorities are the ones usually in charge (Yazawa, 2017). In response to these circumstances, Integrated Watershed Management (IWM) has recently been garnering more attention in the Malaysian local environmental management bodies so that environmental issues can be managed at a watershed scale under the concept of IWM.

IWM is the basic concept of river basin management, and it is a comprehensive countermeasure for water-related problems on account of its effectiveness in handling flood-related problems, its efficiency in controlling water resources, and its ability to ensure high-quality water (Mohamadab et al., 2015). Malaysian IWM principles for flood management have already been established under the history and situation of severe flood disasters (MSMA, 2000). Under the principles of, for example, sustainable flood management, the Sustainable Urban Drainage System (SUDS) has been introduced as one of the Best Management Practices. Some SUDS approaches, such as rainwater harvesting and vegetated infiltration system, have been applied to some pilot areas to reduce runoff rates, runoff volumes, and pollutant loads during storm events (MSMA, 2012; Zakaria, Ghani, Abdullah, Sidek, \& Ainan, 2003, 2004). Since the quantity and quality of water in rivers depend on the climatic situations, natural conditions, and human activities in a watershed, the IWM concept for the integrated management of rivers and their watersheds is vital for the implementation of rational countermeasures (Yazawa, 2017). Successful IWM entails gradual, continuous, and holistic improvement of watershed governance including sustained efforts to integrate institutional responsibilities, policy directions, stakeholder participation, scientific and traditional knowledge, technological possibilities, and funding prospects and constraints (Nakamura \& W., 2014). IWM is a sustainable approach to achieving watershed management that involves relationships between upstream and downstream, lentic and lotic waters, people at large, and the people specifically operating in a watershed (Kondo, 2016).

In that respect, the management of a plantation with a focus on oil palm is one of the most important factors in considering IWM in Malaysia from both the environmental and industrial perspectives. On one hand, this is because Malaysia is one of the largest producers of palm oil (Koh \& Wilcove, 2007). The development of the industry is a vital issue for the country since the palm oil industry provides not only job opportunities for over half a million people in Malaysia and the neighboring countries but also other opportunities, such as housing and basic amenities (Koh \& Wilcove, 2007) as well as subsidies (Bronkhorst et al., 2017). On the other hand, environmental issues, e.g., biodiversity loss, air pollution (i.e., haze), and soil degradation, have occurred because of oil palm plantations. In particular, the impact of the expansion of oil palm plantations on watershed hydrology is not yet clear as will be discussed in subsection 3.2.2. This paper, thus, focuses on one of the serious environmental problems in Malaysia, flooding, and it aims to investigate the feasibility of flood management particularly in oil palm plantations from both social and hydrological aspects. This was done by reviewing the flood situations and their causes in Malaysia, and investigating the actual environment and associated problems in oil palm plantations based on literature reviews and field surveys. The discussion opens opportunities for the local people to participate in the management activities based on the IWM concept by suggesting several feasible flood management strategies reflecting the condition of the local environment. The findings of this research provide new insights into local flood management, which usually focuses on hydrological aspects, by promoting the integration of the actual-local environment and the local people's actions against their environment within the framework of IWM. Achieving the Sustainable Development Goals (SDGs) has also become one of the important factors in the sustainable development of Malaysia (Afroz \& Ilham, 2020). This research also contributes to the achievement of the SDGs related to environmental issues, such as climate change (Goal 13), land degradation (Goal 15), and management with stakeholder's participation (Goal 17) in Malaysia. 


\section{Methodology}

A comprehensive literature review was conducted in this research to reveal the underlying issues related to floods and their causes in Malaysia and the flood management in the Malaysian oil palm plantations and to propose feasible flood management. To review the issues and trends in the management approaches, journal articles, official documents, and online news articles were collected by a means of web search using Google and Google Scholar.

\subsection{Locations of the Field Surveys}

Two field surveys were conducted, with the first in the region near Routes 91 and 93 in the Johor River Watershed in December 2012 [Figure 1 (a)] and the second in the town of Tanjung Karang near the Selangor River Watershed in August 2016 [Figure 1 (b)]. These sites were selected because of the existence of several ownerships of oil palm plantations, such as company-ownership and individual ownership. Farmlands destined for oil palm and rubber plantations occupy $60-70 \%$ of the area of the Johor River Watershed (T., Kim, Sato, \& Shimizu, 2019a) and 40 - 50\% of the area of the Selangor River Watershed (Kondo, 2016).

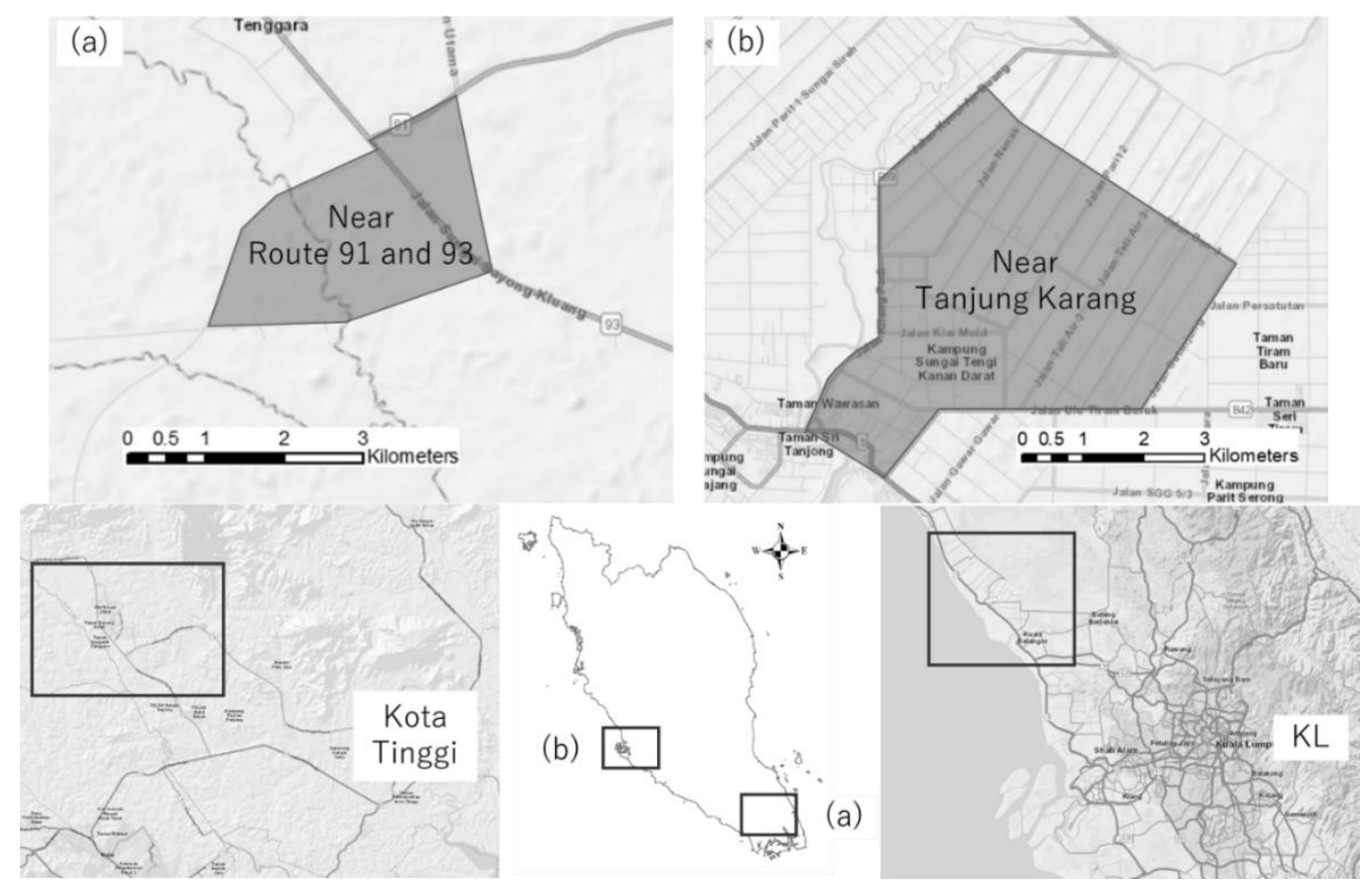

Figure 1. Field survey areas: (a) Near Routes 91 and 93 in the Johor River Watershed and (b) Tanjung Karang near the Selangor River Watershed in Malaysia (Map Source: The ESRI World Street Map)

\section{Methodology}

\subsection{Floods and their Management in Malaysia}

The regions on the Maritime Continent including some Southeast Asian countries, such as Indonesia, the Philippines, Singapore, and Malaysia, and are located in the Tropical Warm Pool. Malaysia frequently suffers from floods and droughts during the El Niño years and the La Niña years respectively since deep cumulus convection and heavy precipitation systems play a major role in the climatic and weather conditions on the Maritime Continent (Chang, Harr, \& Chen, 2005). According to a report published by DID (2009), there are 189 river systems (89 in Peninsular Malaysia, 78 in Sabah, and 22 in Sarawak) flowing directly to the sea. Also, 85 of these are prone to floods, which are caused by a combination of natural and human factors. Natural factors such as heavy monsoon rainfall and intense convection rainstorms have become common features in Malaysia. In particular, heavy rains tend to occur in the two major monsoon seasons, the Southwest (SW) monsoon (from May to September) and the 
Northeast (NE) monsoon (from November to March), and they have a critical influence on floods (Chan, 1995).

According to (Chan, 1997), floods in Malaysia can be categorized as either "normal" or "major" flood events. Normal Floods are regarded as seasonal floods that occur almost every year in the NE monsoon season, particularly on the east coast. The people living in the region have adapted well to the regular floods by constructing houses on stilts so that the water does not exceed the level of the floor. However, the monsoon rains also cause "major" floods which are regarded unusual or extreme events that are difficult to deal with. The northeasterly winds during the NE monsoon season sometimes bring heavy rains and cause prolonged devastating floods, particularly on the east coast of Peninsular Malaysia. On the other hand, the southwesterly winds during the SW monsoon season bring short-lived squalls called "Sumatra," which sometimes cause flash floods on the west coast including the capital area of Kuala Lumpur. However, the floods do not last long. This significant weather condition is caused by the Sumatra squall line which brings in heavy rain not only to Malaysia but also to Singapore (Yi \& Koh., 2007). Meanwhile, rapid land-use changes such as urbanization and deforestation in the region are regarded as human factors that intensify floods (Billa, Mansor, \& Mahmud, 2004). In addition, most of the Malaysian watersheds are mainly occupied by forests in the upper stream, while the lower part of the basin is occupied mainly by farmlands for oil palm and rubber plantations. Although these plantations play a crucial role in the industries in Malaysia, the farmlands have hurt the watershed hydrology with decreased runoff time that can trigger severe floods downstream to where the cities are located (Adnan \& Atkinson, 2011; Yusop, Chan, \& Katimon, 2007).

Recent significant disasters have revealed some of the issues in flood management in Malaysia, such as the incident that occurred in the Johor River Watershed from December 2006 to January 2007 during the NE monsoon season. Two devastating floods with heavy rain hit Peninsular Malaysia, and the Johor River Watershed was one of the most severely damaged areas during the flooding period. When the two devastating floods occurred, Kota Tinggi, an area of the city located downstream of the Johor River, was severely damaged. This is shown in the report of the DID (Department of Irrigation and Drainage Malaysia (2009). DID Manual 1, 2009). During these incidents, the observed maximum water levels in Kota Tinggi were reportedly up to $5.0 \mathrm{~m}$ in December 2006 and $5.5 \mathrm{~m}$ in January 2007. In this area, the dangerous, alert, and normal water levels are 2.8, 2.5, and $2.1 \mathrm{~m}$ respectively (Abdullah, 2013). Most of the city was flooded and many of the residents had to be evacuated. The amount of rainfall during these two events was greater than $400 \mathrm{~mm}$. This exceeds the monthly average value of $200 \mathrm{~mm}$ (Department of Irrigation and Drainage Malaysia (2009). DID Manual 1, 2009; Razi, Ariffin, Tahir, \& Arish, 2010). The reported cost of repairing roads and bridges was about 147 million RM (43.6 million USD). Also, the estimated cost of replacing the hydraulic structures was about 260 million RM (77 million USD) in Johor district alone (Shafie, 2009). The two flood events in the Johor River Watershed between December 2006 and January 2007 are representatives of flooding in Peninsular Malaysia. One of the defining characteristics of Malaysian watersheds is the continuous rainy days during the monsoon season (Muhammad \& Julien, 2015; Muhammad, Julien, \& Salas, 2015; Suhaila \& Jemain, 2007) in addition to short-term heavy rainfall that causes flash flooding. Multiday rainfall events are very common during the monsoon season in the Johor River Watershed. It is well known that flooding is an unavoidable natural phenomenon given the characteristic of such rainfall (Chan, 1995).

Unfortunately, a concrete design flood system that flexibly considers the various watershed's characteristics, depending on the region of focus in Malaysia, has not yet been established. With the changes brought about by global warming, rainfall events, in specific rainfall patterns and frequency of heavy rain, will become even more consequential. It is necessary to accurately predict the river conditions and to effectively mitigate flood damage by implementing efficient flood management measures under the concrete design flood system. In addition to the hydrologic design value, when it comes to conducting the structural measures, reasonable and acceptable countermeasures reflecting the actual watershed condition should be considered to prevent flooding based on the IWM.

\subsection{Flood Management of Oil Palm Plantations}

\subsubsection{Situation of the Palm Oil Industry in Malaysia}

As of 2016, Malaysia was the second-largest producer and exporter of palm oil in the world, only after Indonesia (Nguyen et al., 2014). Although the oil palm plantations play a crucial role in the Malaysian industries, some researchers have warned that they negatively affect watershed hydrology as elaborated 
in the following subsection. These unfavorable situations are caused by the construction of plantations since the processes involved entail soil compression by trucks and tractors. On the other hand, the economic opportunity presented by oil palm plantations cannot be disregarded. Thus, it is obvious that these complex situations regarding oil palm plantations require an IWM approach in Malaysian watersheds to consider the balance of environmental management and the Malaysian economy.

\subsubsection{The General Processes of Palm Oil Production and the Triggered Environmental Problems}

In general, oil palm plantations focus on three cultivation stages: nursery, immature, and mature. The cultivation practices and places differ depending on the stage of the tree's development (Indonesia, n.d.-b, n.d.-a, 1999). The nursery stage is the first stage in the production of seedlings that are sent to the oil palm plantations. Oil palm trees at the nursery are cultivated using polybags. Only at this stage must the oil palm trees be watered and fertilized. From this stage, it takes two or three years to reach maturity that is the last stage, a process described in this subsection. The immature stage is the second part of cultivation, covering one- to two-year-old trees. This is essentially a two-step stage: planting and maintenance. At the planting step, the land is cleared, and roads and drains are constructed to transport the seeds and to prevent root rot. After the roads are built, drains are constructed in the interconnecting series. There are two types of roads: harvest and main roads. The seeds that are produced by the oil palm trees are harvested along the harvest road, collected along the main road, and transported to the palm oil mill. As for the drains, there are three types: field, collection, and main drains. The drain type is determined by size, capacity, and location. All drains are designed to reduce water retention time in the oil palm plantations. The field and collection drains are connected to the main drain, which eventually connects to a neighboring river. Maintenance follows the planting step. Maintenance operations, such as weeding and fertilizer application, are implemented during this step. The mature stage covers oil palm trees that are three years old and older, and oil palm trees that continue fruiting for approximately 25 years. After that, the trees are cut, burned, and fertilized. New oil palm trees are then prepared, and the oil palm plantation reverts to the nursery stage.

As the industry is developing, some of the environmental issues caused by oil palm plantations, such as biodiversity loss and air pollution, have been discussed by researchers. Palm oil is primarily used in snacks and cosmetics. Oil palm trees usually grow in areas that were once peatlands or wet areas where dead organic material is plentiful. These days, peatlands are dried for agricultural purposes as quickly as possible (Dohong, Aziz, \& Dargusch, 2017). Swidden cultivation, or slash-and-burn cultivation, which only degrades the area and surrounding environment, sometimes entails illegal draining and burning of the land (Dohong et al., 2017). Recently, air pollution (i.e., haze) has become a serious problem in Malaysia. This haze spreads and causes hazy weather both in Malaysia and in neighboring countries. Extensive swathes of natural forest and tropical rainforest have been lost due to logging for the construction of oil palm plantations (Dohong et al., 2017; Yazawa, 2017). Also, the effluent from the oil palm plantations finding its way into the rivers degrades the water quality, which is another problem stemming from oil palm plantations (Yazawa, 2017). The conversion of forests and the expansion of oil palm plantations also affect the biodiversity in the region because oil palm plantations can support fewer species than natural forests (Fitzherbert et al., 2008; Koh \& Wilcove, 2008). Furthermore, the watershed hydrology is also affected by the conversion from forest to oil palm/rubber plantations. Merten et al. (2016) mentioned that the conversion causes soil degradation and thus the soil permeability in oil palm plantations is low. Compressed soil reduces the amount of water infiltrating into the ground (Merten et al., 2016; Yusop et al., 2007; Ziegler, Fox, \& Xu, 2009). This situation causes higher surface runoff, peak flows, and eventually flooding of the oil palm plantations during rainfall events. However, the impact caused by the existence of plantations on watershed-scale hydrology, particularly flooding, is still under debate. Majizat (Majizat, Ahmad, \& Noordin, 2009) and Rahaman (Rahaman, Noordin, Sahat, Muhamad, \& Majizat, 2010) explain that cutting rubber and oil palm trees may cause an increase in surface runoff and flooding. Thus, it is necessary to clarify the impact of the life cycle of oil palm plantations on watershed hydrology using hydrological techniques, such as modeling, since the expansion of oil palm plantations is expected to continue in the future. Although more scientific and hydrological investigations are needed to reveal the causes of flooding, Malaysia is still susceptible to flooding because the plantation areas continue to expand for economic benefit. 


\subsection{Insights from Field Surveys on Oil Palm Plantations}

\subsubsection{Condition of the Oil Palm Plantations in the Field Survey Areas}

Ramasamy (Ramasamy, Ong, \& Yeung, 2005) stated that ownership is one of the important factors in considering the profitability of the Malaysian palm oil sector. There are four categories of industrial ownership: privately owned (mainly company-owned), government-owned, state-owned, and smallholders (individually owned). The oil palm plantations in the field survey sites of this research are either individually owned or company-owned. There are significant differences in the management strategies employed by these two types of ownerships because land use is already destined by the land categories which have been established by the government. The land categories determine the types of activities that can be carried out on said land, including residential, agricultural, industrial, commercial, or other purposes. People or companies in Malaysia can start oil palm plantations and paddy fields when the land they possess is categorized as agricultural.

For the most part, mature oil palm trees do not require maintenance, and they continue fruiting for approximately 25 years without being attended. Thus, oil palm trees are easy to maintain and offer significant income opportunities, which explains the high number of individually-owned oil palm plantations in Malaysia. Since the people who individually own oil palm plantations usually do not carry out any maintenance, owning an oil palm plantation is still popular with individuals. Figure 2 shows the (a) individually-owned and (b) company-owned oil palm plantations observed in the field survey areas. The differences in maintenance conditions between these two types of oil palm plantations are on full display in Figure 2. The ground of the company-owned oil palm plantations is kept clean, whereas the ground of individually-owned oil palm plantations is left as it is.

Company-owned oil palm plantations account for a much greater share of land than individuallyowned ones. The companies hire many workers, including local and foreign workers, to efficiently maintain and systematically manage the land (Koh \& Wilcove, 2007). As shown in Figure 2 (b), the companies have workers remove fallen leaves from the ground, weed the area, and then fertilize the soil using chemical or organic fertilizers to accelerate tree growth/fruit production. Over the past few decades, company-owned oil palm plantations have used chemical fertilizers that have degraded the quality of river water, particularly when heavy rains and subsequent surface runoff occur. Accordingly, some companies have recently shifted to using organic fertilizers (Ismail, Zulkifli, \& Azmi, 2010).
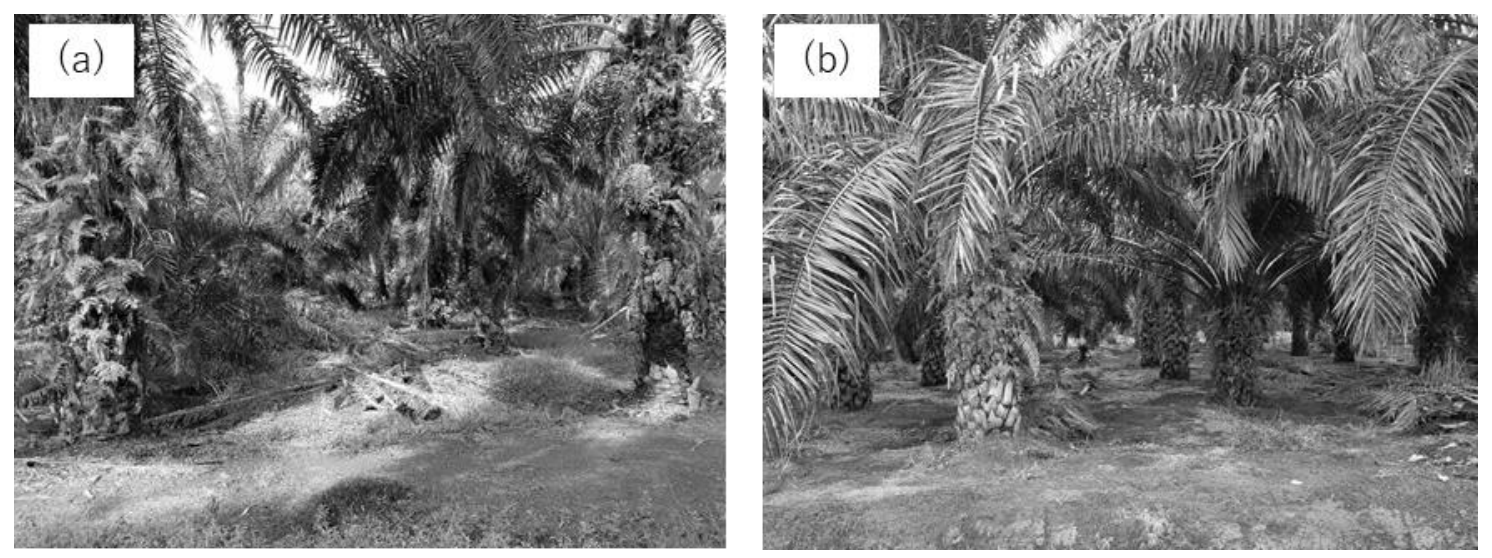

Figure 2. (a) Individually-owned and (b) Company-owned oil palm plantations in the field survey areas

\subsubsection{Flooding in Oil Palm Plantations}

In oil palm plantations, rainwater can be the only water source, i.e., there is no need to prepare an artificial water supply system. This facilitates the locals in starting their oil palm plantation business by reducing the initial cost. The fallen leaves are left because they play an important role in maintaining the soil moisture of oil palm plantations owned by individuals that do not usually have workers/employees to maintain vast areas. Oil palm trees grow sufficiently with no more than soil moisture. This makes it easier for the locals to keep their oil palm plantation business by reducing the maintenance cost and manpower needed. If oil palm trees are overwatered, the fruits produced are of lower quality and they may even be 
rotten. This means that flooding is far from desirable, particularly for private owners. This is because flooding brings in too much water, and surface runoff washes fallen leaves away. Moreover, floods carry soil away, and this causes sedimentation in rivers and clogging in drainage canals.

During the December 2012 field survey in the Johor River Watershed, flooding was observed on an individually-owned oil palm plantation (Figure 3). Given that December is in the Northeast (NE) monsoon season, rainy days continued during the period of the field survey. Such weather situations can easily trigger flooding, and individually-owned oil palm plantations are particularly vulnerable to flooding because they are not maintained and because fallen leaves clog drainage canals. Both individually- and company-owned oil palm plantations usually have small drains (i.e., field and collection drains) between the trees; these small drains connect to the main drain, and the main drain connects to an artificial drain or river. The water in the artificial drains eventually flows into the neighboring bodies of water, whether they are rivers or the sea. For company-owned oil palm plantations, drains are usually constructed in accordance with established rules, and they are maintained by workers to effectively discharge stagnant water. In the case of individually-owned oil palm plantations, artificial drains connect to a neighboring river. However, these drains are designed based on the locals' experiences, and they do not follow a systematic design. Additionally, these drains are rarely managed, and thus overflowing often occurs due to clogging caused by accumulated leaves, garbage, sediment, and weeds, etc., all of which reduce drainage capacity. Therefore, the drainage system and its maintenance should be addressed by oil palm plantation owners with appropriate fallen leaf management to make sure enough soil moisture and to keep adequate drain capacity to handle rainfall in the rainy season.

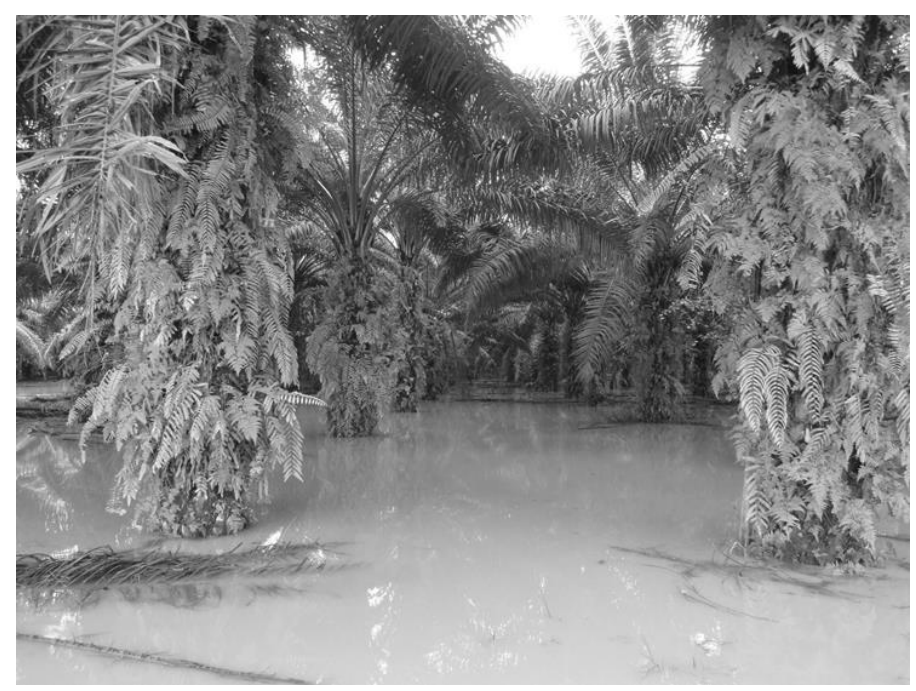

Figure 3. Flooding on an oil palm plantation in the Johor River Watershed, Malaysia (December 2012)

\subsubsection{Co-existence and Harmonization with Paddy Fields}

In the town of Tanjung Karang, there is an excellent example of an oil palm plantation with an adjacent paddy field. This ensures that the water is balanced by a give-and-take relationship. Most drains in the paddy field are also connected to the same main drains in the oil palm plantation. The DID controls the water by using water gates that are adjusted to the paddy field's water level, thereby ensuring that the water level of the paddy field remains constant. As mentioned above, an excessive water supply is detrimental to oil palm plantations. Paddy fields, on the other hand, require water. Thus, connecting an oil palm plantation and a paddy field with a drainage canal means that almost any irrigation system can take advantage from flooding. The local people in Tanjung Karang told us that they had never experienced flooding on their oil palm plantations. Thus, the co-existence of oil palm plantations and paddy fields has proven to be advantageous. In general, as shown in Figure 4, paddy field drains are highly managed and maintained compared to those of oil palm plantations. This gap in drain maintenance indicates the importance of controlling the amount of water/water level in the paddy fields, which is in contrast to the relative unimportance of water management in oil palm plantations. In the dry season, paddy fields must have their water levels adjusted. Therefore, the water gates dam up in the paddy fields during the dry season resulting in limited rainfall. Occasionally, this limits the downstream flow of the connected river. 
During the field survey conducted near the Selangor River Watershed in August 2016, the days without rains were prolonged on account of the El Niño phenomenon, which limited the observed downstream flow of the paddy fields. Also, just outside the paddy fields, there was a significant amount of garbage at the mouth of the drain as shown in Figure 5. Trash returned to the top and it often clogged the water gate which, in turn, hindered the effective water management in the paddy fields as well as that of the oil palm plantations. Given that the co-existence of oil palm plantations with paddy fields produces a harmonious effect in terms of floodwater management in both fields during periods of heavy rain, resolving these issues would be substantially beneficial to the owners.

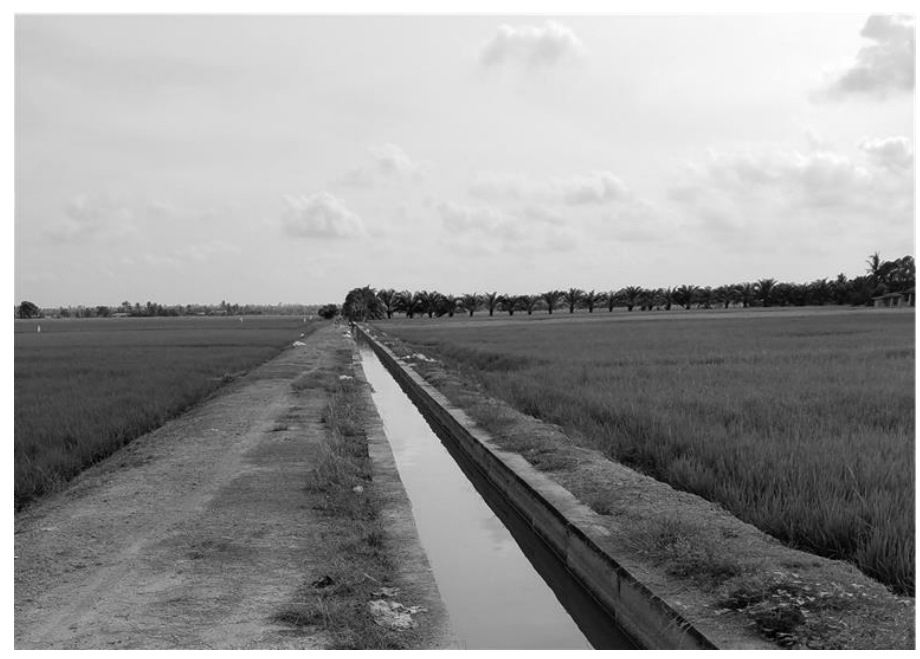

Figure 4. Drain in a paddy field in Tanjung Karang, Malaysia (August 2016)

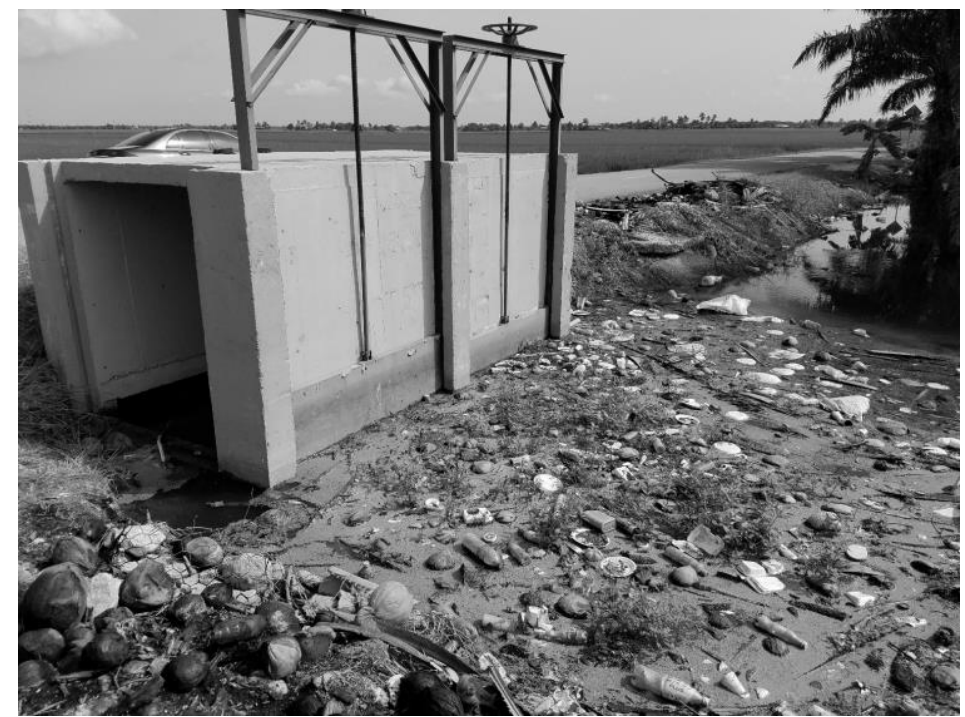

Figure 5. Garbage in the drain near the water gate connected to a paddy field (August 2016)

\subsubsection{Retention and Detention Ponds in the Field Survey Areas}

Retention (wet) and/or detention (dry) ponds are known as multifunctional basins that temporarily store water during heavy rains and mitigate flooding in addition to for recreational and aesthetical uses (Loc, 2013). If an oil palm plantation has retention and/or detention ponds, flooding may be prevented or mitigated. These plantations are especially benefitted from the excessive water storage in the ponds during periods of heavy rain. During the field survey of the Johor River Watershed in December 2012, the rain events lasted several days because December is part of the NE monsoon season; flooding was observed as shown in Figure 3. The field survey left no doubt that there were no satisfactory retention and detention ponds or drainage capacity in the study area. 
In contrast, during the field survey in Tanjung Karang in March 2016, three retention ponds were confirmed within the region. Based on interviews with the locals, the retention ponds were identified as being used for "commercial use", namely fishing. They are not considered to be retention ponds for water storage, and thus they are not maintained. One of the three retention ponds is artificial and is used by the DID to check the water quality of neighboring drains. However, the pond is not controlled for water storage and the local people can use it for fishing even though the water quality is monitored by a local governmental institute. The other two (natural) retention ponds are not managed either. However, they are directly linked to oil palm plantations.

Even though the local people of Tanjung Karang have not yet experienced flooding, that does not mean that they are free from flooding in the future caused by climate change. To mitigate and prevent damage from flooding in the oil palm plantations, retention ponds should be used and maintained. Such ponds have been used commercially and individually up until now, with the hope that more ponds to avoid flooding will be constructed on bare land that is generally neglected by the locals.

\subsection{Feasible Flood Management in Oil Palm Plantations}

\subsubsection{Factors to Ponder for the Effectiveness of Management}

Certain flooding countermeasures have not yet been well recognized at the local level of the plantation area, as observed from the findings of the field surveys, even though the oil palm plantations in some regions in Malaysia (e.g., the Johor River Watershed) have been flooded almost every year (T. et al., 2019a). Additionally, the management approach and the owners' awareness are different between individually-owned and company-owned oil palm plantations. In particular, individually-owned oil palm plantations significantly affect the local environment, e.g., watershed environment. In Tanjung Karang, there have been almost no problems regarding flooding until recently, as some existing drains have sufficient capacity and the co-existence of plantations and paddy fields manages the floodwater during heavy rain. However, the increased frequency of rainfall and flooding events is predicted to occur because of the future climate change in Malaysia that has been discussed by many researchers (Hassan, 2012; Juneng \& Tangang, 2008; Kwan, Tangang, \& Juneng, 2013; Shaaban, Amin, Chen, \& Ohara, 2011; T. et al., 2019b; Tan, Ficklin, Ibrahim, \& Yusop, 2014; Tukimat \& Harun, 2011). The capacity of the existing drains is unlikely to be able to handle the extreme events predicted. Certain flood management strategies, therefore, must be implemented for both existing and potential oil palm plantations with the proper understanding and participation of the local people. According to Dumanski and Peiretti (Dumanski \& Peiretti, 2013), when planning land management, the following factors must be taken into account: how to maintain and enhance production (productivity), how to reduce production risk (stability), how to enhance soil capacity (resilience), how to protect the natural resources/prevent the degradation of soil and water quality (protection), how to ensure economic viability (viability), and how to garner social acceptance (acceptability). Based on these criteria in conjunction with the findings from the field surveys and the literature review, several feasible flood management strategies for use in oil palm plantations are suggested below along with several case studies.

\subsubsection{Effective Use of Retention and/or Detention Ponds}

Retention and detention ponds are general and conventional methods for managing floodwater. These ponds collect flood water and slowly release it at a controlled rate. Hence, they also prevent flooding in downstream areas. The main difference between retention and detention ponds is that the former is wet, i.e., it has permanent water, and the latter is dry, i.e., occasionally wet. The ponds themselves are effective and important for storing and attenuating surface runoff (Sustainable Stormwater Management, 2009). Therefore, the effective use of existing retention ponds, e.g., the ponds currently used only for fishing in Tanjung Karang, means that they will be able to play a crucial role in preventing and mitigating flooding in oil palm plantations with minimal improvements needed.

Retention ponds are multifunctional basins that function as an important source of irrigation water supply, as retarding basins for local residents, and as a temporary water storage basin during a flood (Loc, 2013). Retention ponds play an important role in cutting peak flow, delaying surface runoff time, and reducing sediment and pollutants attached to sediments (Robinson, Scholz, Bastien, \& Carfrae, 2010). Retention ponds are an online storage facility that permanently retains water, thus keeping the water out of the groundwater table. They have an orifice at a higher point to retain a permanent pool of 
water (Sustainable Stormwater Management, 2009). Detention ponds are also multifunctional basins with the primary function as a temporary water storage basin during flooding. However, it is an offline form of storage that only detains water during heavy rainfall. Detention ponds drain all of the water after the end of a rainfall event. Their orifice is located at the bottom of the basin so that all water eventually drains out, which means that they remain dry between rainy events (Sustainable Stormwater Management, 2009). Given that they are dry between rainy events, land use control brings in additional benefits. For example, detention ponds designed for flood control may also serve as sports facilities for the community (Tucci, 2001). Parkinson and Mark (Parkinson \& Mark, 2005) designed a detention pond as a soccer field in Brazil. Thus, detention ponds can not only help in flood control but also offer recreational value. In Malaysia, there is a successful example of Putrajaya Lake and Wetland. Putrajaya Lake has a water catchment area of $51 \mathrm{~km} 2$, and the wetland is the first man-made wetland in Malaysia. The quality of the lake water is maintained at a certain level which allows people to use the lake for sports and recreational activities (Majizat et al., 2009; Rahaman et al., 2010). When Putrajaya Lake and Wetland were constructed, their hydrological roles in flood mitigation, storm and flood storage, peak flow reduction, and groundwater recharge were also taken into consideration. They both prevent flooding in Putrajaya where the government center is located. From the perspectives of efficiency, sustainability, and acceptability, these ponds will prove valuable in the fight to mitigate flooding, and they will also offer recreational value as recreational sites for locals even in urban areas.

Although retention and detention ponds have various functions, maintenance is one of the most important elements to ensure their utility. The retention pond's orifices are sometimes clogged by pollutants and garbage. Similarly, the detention pond's orifices are often clogged by pollutants and garbage due to the orifices' location, i.e., at the bottom of the pond. Therefore, maintenance activities, including erosion repair, sediment removal, and vegetation management, are necessary for proper functioning. This requires understanding and participation of the locals.

\subsubsection{Improvement of the Drainage System}

The three types of drains (field, collection, and main) in the oil palm plantations and their concomitant construction rules have been discussed. Although the drains in the company-owned oil palm plantations are well-maintained to effectively discharge water, those in individually-owned oil palm plantations are sometimes not. Flooding often occurs because of clogging caused by accumulated garbage, sediment, weeds, etc. In other words, there is a lack of maintenance. This leads to an inadequate drainage capacity in the rainy season. For that reason, individually-owned oil palm plantations are vulnerable to flooding, which highlights the importance of drainage systems and their maintenance. In this case, the owners' awareness is highly relevant. When the locals construct their oil palm plantations, they should not only actively count on their experiences but also follow certain guidelines or criteria. The wisdom, knowledge, perception, and experiences of the locals should primarily be respected as "bits of wisdom" for future generations, incorporated into practical management, and integrated in line with IWM. Technical guidelines or criteria will also be effective when it comes to preventing flooding in oil palm plantations. Also, given the impact of climate change on the frequency and intensity of flooding, the current construction rules and guidelines for drainage design systems in oil palm plantations might not be satisfactory. They must be revised to improve the drain capacity to cope with future flooding. Moreover, the participation of the locals in maintenance activities such as garbage collection and removal of weeds from the drains is crucial because stakeholder participation is one of the pillars of IWM. Thus, it is vital to reflect on the ways in which local people participate and to facilitate their understanding of the underlying issues discussed herein. It should be noted, however, that the downstream peak flow rate might increase because of the management activities at the upper stream. In that sense, a discussion of the people between upstream and downstream would become more important in the IWM concept.

\subsubsection{Management of Fallen Leaves}

According to Tarigan (Tarigan et al., 2016), the expansion of oil palm plantations reduces the regulatory function of watershed's waters because of increased surface runoff. Their research thus proposed two flood mitigation options: frond pile management and a combination of frond pile management and silt pit treatment. Both options represent simple ways to enhance the locals' adoption and sustainable application. They can reduce surface runoff by approximately $10-30 \%$. These options are considered to be ecologically effective and economically viable because the implementation costs are 
low. They also satisfy the land management criteria suggested by Dumanski and Peiretti (Dumanski \& Peiretti, 2013). Based on the pilot study conducted by Tarigan (Tarigan et al., 2016) in the Merangin Tembesi Watershed in Indonesia, fallen leaf management is also effective. Its implementation requires understanding and cooperation from local people, and above all those who have individually-owned oil palm plantations because these owners generally leave leaves on the ground. The difficulty of enacting this strategy is compounded by the belief of the local community that fallen leaves provide the advantage of keeping moisture in the soil so that the trees bear more and better fruits. However, fallen leaves cause flooding and clogged drains. Managing fallen leaves can reduce the clogging of drains during heavy rain. This is better for the locals insofar as it allows them to understand the pros and cons of their lack of maintenance. By being armed with that understanding, the locals can implement appropriate fallen leaf management. More scenario simulations using hydrologic models would be helpful to evaluate the effects of fallen leaf management and its effectiveness in facilitating the understanding of the locals in light of engineering.

\subsubsection{Non-structural Flood Management Approach}

People living in the regions vulnerable to flooding usually construct houses on stilts so that water does not exceed the floor height (Chan, 1997). This is a clear example of the locals' adaptation to flooding conditions based on their experience and this demonstrates how they respect their ancestors' experiences. However, when we consider the future impacts of climate change, there is a lingering doubt as to how people will adapt to more severe floods in the future. In this case, non-structural flood management will become a key factor in the preparation for future floods. Non-structural measures reduce flood damage through non-constructive solutions (i.e., solutions that do not involve construction) as well as flood management plans. Wing (Chia, 2004) suggested non-structural measures to effectively avoid a flood. For example, flood forecasting and an early warning system are important, practical, and low-cost measures to minimize flood damage. These are currently the most acceptable and applicable ways for local people to handle floods in the era of ubiquitous smart devices with internet connections.

Population relocation/resettlement is another non-structural measure traditionally implemented in Malaysia to reduce the potential damage and loss of life in areas that are prone to flooding. In particular, this method is effective for areas where floods cannot be significantly reduced by structural measures. The Malaysian government has already prepared many relocation/resettlement schemes as a part of flood management (Chan, 1995). For example, 1,672 and 2,715 families from the states of Kelantan and Pahang respectively have been resettled since 1971 because these areas are known as the most flood-prone areas in the country (Chia, 2004). However, there have been only a few cases of relocation/resettlement because of its unpopularity and high cost. It is considered to be the worst and last option by the locals who, naturally, do not want to incur the hardship of relocation/resettlement, i.e., preparing alternative locations and houses, losing contact with their relatives, friends, and places of work or schools, and getting acclimated to their new environment (Chan, 1995). Having said that, the locals have already recognized that moving to other places with a higher elevation is effective in mitigating the damage of floods (Iya, Gasim, Toriman, \& Abdullahi, 2014). Iya (lya et al., 2014) proposed an alternative, suggesting a flood-fighting drill for the locals and encouraging them to participate in the drill. This is in addition to the development of housing that is designed to mitigate floods (flood-proofing).

\section{Conclusions}

Malaysian watersheds have historically suffered from severely damaging floods because of the monsoonal climatic characteristics. To achieve successful IWM in Malaysia, the real situations of the target watershed should be comprehensively considered before any practical strategies are applied. The conditions and underlying issues of flood management in the Malaysian main industry, oil palm plantations, have been reviewed and summarized in this research. As a result, feasible flood management strategies have been proposed based on the findings of both the field surveys and the literature review of the concept of IWM.

The Malaysian palm oil industry is one of the important factors when we consider IWM because it is the most dominant land use in most of Malaysian watersheds. It was revealed that local people's awareness and ownership strongly affect the management of oil palm plantations and sometimes lead to environmental problems such as flooding. The unattended oil palm plantations triggers flooding during heavy rain because fallen leaves, garbage, sediment, and weeds clog drainage canals, leading to 
inadequate drain capacity. Thus, this research has presented feasible flood management strategies for oil palm plantations including effective use of the retention and detention ponds, improvement of the drainage systems, management of fallen leaves, and a design of a non-structural approach.

In balance, effective IWM requires consideration of structural and/or non-structural measures that rely on preventive and adaptive countermeasures in addition to fostering understanding and participation in planning among the locals to comply with IWM principles. Even though this research discusses differences in the management strategies of company-owned and individually-owned plantations, it should be emphasized that this research does not aim to determine which strategy is better because the local people's interests, knowledge, and experiences must be respected based on the concept of IWM. Thus, what we have to consider is enhancing the locals' understanding and promoting their participation. It is incumbent upon further flood management research to evaluate suggested countermeasures using engineering techniques, such as hydrological modeling. Therefore, the effectiveness of feasible flood management strategies including the ones discussed in this article should be assessed so that evidence-based management plans to convince stakeholders could be proposed.

\section{Acknowledgments}

This work was conducted under the framework of "Research and Education Center for the Risk-Based Asian Oriented Integrated Watershed Management", supported by the JSPS Asian Core Program and Ministry of Education, Malaysia.

\section{References}

Abdullah, J. (2013). Distributed Runoff Simulation of Extreme Monsoon Rainstorms in Malaysia using TREX. Colorado State University.

Adnan, N. A., \& Atkinson, P. M. (2011). Exploring the impact of climate and land use changes on streamflow trends in a monsoon catchment. International Journal of Climatology, 31(6).

Afroz, N., \& Ilham, Z. (2020). Assessment of Knowledge, Attitude, and Practice of University Students towards Sustainable Development Goals (SDGs). The Journal of Indonesia Sustainable Development Planning, 1(1).

Billa, L., Mansor, S., \& Mahmud, A. R. (2004). Spatial information technology in flood early warning systems: An overview of theory, application, and latest developments in Malaysia. Disaster Prevention and Management: An International Journal, 13(5).

Bronkhorst, E., Cavallo, E., Medler, M.-M. van D. tot, Klinghammer, S., Smit, H. H., Gijsenbergh, A., \& Laan, C. van der. (2017). Current practices and innovations in smallholder palm oil finance in Indonesia and Malaysia: Long-term financing solutions to promote sustainable supply chains. Bogor: CIFOR.

Chan, N. W. (1995). Flood disaster management in Malaysia: An evaluation of the effectiveness of government resettlement schemes. Disaster Prevention and Management: An International Journal, 4(4).

Chan, N. W. (1997). Increasing Flood Risk in Malaysia: Causes and Solutions. Disaster Prevention and Management: An International Journal, 6(2).

Chang, C. P., Harr, P. A., \& Chen, H. J. (2005). Synoptic Disturbances over the Equatorial South China Sea and Western Maritime Continent during Boreal Winter. Monthly Weather Review, 133(3).

Chia, C. W. (2004). Managing flood problems in Malaysia. Bulletin Ingenieur.

Department of Irrigation and Drainage Malaysia (2009). DID Manual 1, P. 5.-1. (2009). DID Manual 1, p.5A1.

Dohong, A., Aziz, A. A., \& Dargusch, P. (2017). A Review of the Drivers of Tropical Peatland Degradation in South-East Asia. Land Use Policy, 69.

Dumanski, J., \& Peiretti, R. (2013). Modern concepts of soil conservation. International Soil and Water Conservation Research, 1(1).

Fitzherbert, E. B., Struebig, M. J., Morel, A., Danielsen, F., Brühl, C. A., Donald, P. F., \& Phalan, B. (2008). How will oil palm expansion affect biodiversity? Trends in Ecology and Evolution, 23(10).

Hassan, Z. (2012). Application of Statistical Downscaling Model for Long Lead Rainfall Prediction in Kurau River Catchment of Malaysia. Malaysian Journal of Civil Engineering, 24(1).

Indonesia, I. P. N. I. and P. A. S. (n.d.-a). Oil Palm Series -Mature-, Field Handbook 3.

Indonesia, I. P. N. I. and P. A. S. (n.d.-b). Oil Palm Series -Nursery-, Field Handbook 1.

Indonesia, I. P. N. I. and P. A. S. (1999). Oil Palm Series -Immature-, Field Handbook 2. 
Ismail, S., Zulkifli, R., \& Azmi, K. (2010). Crops and Livestock Integration with Oil Palm. In Further Advances in Oil Palm Research, 2000-2010 1 (pp. 543-568).

Iya, S. G. D., Gasim, M. B., Toriman, M. E., \& Abdullahi, M. G. (2014). Floods in Malaysia: Historical Reviews, Causes, Effects and Mitigations Approach. International Journal of Interdisciplinary Research and Innovations, 2(4).

Juneng, L., \& Tangang, F. T. (2008). Level and Source of Predictability of Seasonal Rainfall Anomalies in Malaysia using Canonical Correlation Analysis. International Journal of Climatology, 28.

Koh, L. P., \& Wilcove, D. S. (2007). Cashing in palm oil for conservation. Nature, 448(7157).

Koh, L. P., \& Wilcove, D. S. (2008). Is oil palm agriculture destroying tropical biodiversity? Conservation Letters, 1(2).

Kondo, T. (2016). Prediction of Water Resource in the Future in Selangor River Watershed, Malaysia using a Distributed Watershed Model. Kyoto University.

Kwan, M. S., Tangang, F. T., \& Juneng, L. (2013). Projected changes in future climate extremes in Malaysia. Sains Malaysiana, 42(8).

Loc, H. H. (2013). Integrated Assessment of Sustainable Urban Drainage Systems in Ho Chi Minh City, Viet Nam. Asian Institute of Technology, Bangkok.

Majizat, A., Ahmad, B., \& Noordin, N. (2009). Integrated Catchment Management of Urban Man-made Lake and Wetlands-Putrajaya Experience. Putrajaya, Malaysia: Putrajaya Corporation.

Merten, J., Röll, A., Guillaume, T., Meijide, A., Tarigan, S., Agusta, H., ... Hölscher, D. (2016). Water scarcity and oil palm expansion: Social views and environmental processes. Ecology and Society, 21(2).

Mohamadab, Z. F., Nasaruddin, A., Kadir, S. N. A., Musa, M. N., Ong, B., \& Sakai, N. (2015). Communitybased Shared Values as a 'Heart-ware' Driver for Integrated Watershed Management: JapanMalaysia Policy Learning Perspective. Journal of Hydrology, 530.

MSMA. (2000). Urban Stormwater Management Manual for Malaysia (Volume 4/C). Department of Irrigation and Drainage.

MSMA. (2012). Urban Stormwater Management Manual for Malaysia. Department of Irrigation and Drainage.

Muhammad, N. S., \& Julien, P. Y. (2015). Multiday Rainfall Simulations for Malaysian Monsoons. ISFRAM 2014. Springer, Singapore.

Muhammad, N. S., Julien, P. Y., \& Salas, J. D. (2015). Probability structure and return period of multiday monsoon rainfall. Journal of Hydrologic Engineering, 21(1).

Nakamura, M., \& W., R. (2014). Development of ILBM Platform Process Evolving Guidelines through Participatory Improvement, 2nd ed. Otsushigyo Photo Printing Co. Ltd., Otsu.

Nguyen, M. T., Walle, D. Van de, Petit, C., Beheydt, B., Depypere, F., \& Dewettinck, K. (2014). Mapping the Chemical Variability of Vegetable Lecithins. Journal of the American Oil Chemists' Society, 91(7).

Parkinson, J., \& Mark, O. (2005). Urban Stormwater Management in Developing Countries. London: IWA publishing.

Rahaman, N. A., Noordin, N., Sahat, R., Muhamad, Y., \& Majizat, A. H. (2010). Putrajaya Lake and Wetlands-Current Status and Lesson Learned. National Seminar on Lake and Its Basin. Putrajaya.

Ramasamy, B., Ong, D., \& Yeung, M. C. H. (2005). Firm Size, Ownership, and Performance in the Malaysian Palm Oil Industry. Asian Academy of Management Journal of Accounting and Finance, 1(1).

Razi, M. A. M., Ariffin, J., Tahir, W., \& Arish, N. A. M. (2010). Flood Estimation Studies using Hydrologic Modeling System (HEC-HMS) for Johor River, Malaysia. Journal of Applied Sciences, 10(11).

Robinson, M., Scholz, M., Bastien, N., \& Carfrae, J. (2010). Classification of different sustainable flood retention basin types. Journal of Environmental Sciences, 22(6).

Shaaban, A. J., Amin, M. Z. M., Chen, Z. Q., \& Ohara, N. (2011). Regional Modeling of Climate Change Impact on Peninsular Malaysia Water Resources. Journal of Hydrologic Engineering, 16(12).

Shafie, A. (2009). Extreme Flood Event: A Case Study on Floods of 2006 and 2007 in Johor Malaysia. Colorado State University, Colorado.

Suhaila, J., \& Jemain, A. A. (2007). Fitting daily rainfall amount in Malaysia using the normal transform distribution. JApSc, 7(14).

Sustainable Stormwater Management. (2009). Stormwater 101: Detention and Retention Basins. Retrieved July 1, 2020, from https://sustainablestormwater.org website: https://sustainablestormwater.org/2009/05/28/stormwater-101-detention-and-retentionbasins/ 
T., Y., Kim, S., Sato, K., \& Shimizu, Y. (2019a). Estimation of Design Flood Criteria toward Integrated Watershed Management in the Johor River Watershed, Malaysia. Journal of EICA, 24.

T., Y., Kim, S., Sato, K., \& Shimizu, Y. (2019b). Future Changes in Watershed-scale Rainfall Characteristics: Application of AGCM20 to the Johor River Watershed. Journal of EICA, 23(4).

Tan, M. L., Ficklin, D. L., Ibrahim, A. L., \& Yusop, Z. (2014). Impacts and uncertainties of climate change on streamflow of the Johor River Basin, Malaysia using a cmip5 general circulation model ensemble. Journal of Water and Climate Change, 5(4).

Tarigan, S. D., Sunarti, Wiegand, K., Dislich, C., Slamet, B., Heinonen, J., \& Meyerc, K. (2016). Mitigation options for improving the ecosystem function of water flow regulation in a watershed with the rapid expansion of oil palm plantations. Sustainability of Water Quality and Ecology, 4.

Tucci, C. 'E. M. (2001). Urban Drainage in the Humid Tropics. Paris: UNESCO International Hydrology Program.

Tukimat, N. N. A., \& Harun, S. (2011). The Projection of Future Rainfall Change over Kedah, Malaysia with the Statistical Downscaling Model. Malaysian Journal of Civil Engineering, 23(2).

Yazawa, T. (2017). Design Flood Criteria toward Integrated Watershed Management in the Johor River Watershed, Malaysia. Kyoto University.

Yi, L., \& Koh., T. H. (2007). Analysis and prediction of Sumatra squall lines. 22nd Conference on Weather Analysis and Forecasting/18th Conference on Numerical Weather Prediction.

Yusop, Z., Chan, C. H., \& Katimon, A. (2007). Runoff characteristics and application of HEC-HMS for modeling stormflow hydrograph in an oil palm catchment. Water Science \& Technology, 56(8).

Zakaria, N. A., Ghani, A. A., Abdullah, R., Sidek, L. M., \& Ainan, A. (2003). Bio-ecological Drainage System (BIOECODS) for Water Quantity and Quality Control. International Journal of River Basin Management, 1(3).

Zakaria, N. A., Ghani, A. A., Abdullah, R., Sidek, L. M., \& Ainan, A. (2004). Bio-ecological Drainage System (BIOECODS): Concept, Design, and Construction. Advances in Hydroscience and Engineering, 1(3).

Ziegler, A. D., Fox, J. M., \& Xu, J. (2009). The rubber juggernaut. Science, 324(5930). 